\title{
Transport of EDTA into cells of the EDTA- degrading bacterial strain DSM 9103
}

\author{
Margarete Witschel, ${ }^{1}$ Thomas Egli, ${ }^{1}$ Alexander J. B. Zehnder, ${ }^{1}$ \\ Ernst Wehrli ${ }^{2}$ and Max Spycher ${ }^{3}$
}

Author for correspondence: Thomas Egli. Tel: + 411823 5158. Fax: + 4118235547.
e-mail : egli@eawag.ch

\footnotetext{
1 Department of

Microbiology, Swiss

Federal Institute of

Environmental Science and

Technology (EAWAG) and

Swiss Federal Institute of

Technology (ETH),

Überlandstrasse 133,

$\mathrm{CH}-8600$ Dübendorf,

Switzerland

2 Laboratory for Electron Microscopy, Swiss Federal Institute of Technology (ETH), CH-8092 Zürich, Switzerland

3 Department of Pathology, University Hospital Zürich, $\mathrm{CH}-8091$ Zürich,

Switzerland
}

In the bacterial strain DSM 9103, which is able to grow with the complexing agent EDTA as the sole source of carbon, nitrogen and energy, the transport of EDTA into whole cells was investigated. EDTA uptake was found to be dependent on speciation: free EDTA and metal-EDTA complexes with low stability constants were readily taken up, whereas those with stability constants higher than ${ }^{10^{16}}$ were not transported. In EDTA-grown cells, initial transport rates of CaEDTA showed substrate-saturation kinetics with a high apparent affinity for CaEDTA (affinity constant $K_{t}=0.39 \mu \mathrm{M}$ ). Several uncouplers had an inhibitory effect on CaEDTA transport. CaEDTA uptake was also significantly reduced in the presence of an inhibitor of ATPase and the ionophore nigericin, which dissipates the proton gradient. Valinomycin, however, which affects the electrical potential, had little effect on uptake, indicating that EDTA transport is probably driven by the proton gradient. Of various structurally related compounds tested only $\mathrm{Ca}^{2+}$-complexed diethylenetriaminepentaacetate (CaDTPA) competitively inhibited CaEDTA transport. Uptake in fumarate-grown cells was low compared to that measured in EDTA-grown bacteria. These results strongly suggest that the first step in EDTA degradation by strain DSM 9103 consists of transport by an inducible energy-dependent carrier. Uptake experiments with ${ }^{45} \mathrm{Ca}^{2+}$ in the presence and absence of EDTA indicated that $\mathrm{Ca}^{2+}$ is transported together with EDTA into the cells. In addition, these transport studies and electron-dispersive $X$-ray analysis of electron-dense intracellular bodies present in EDTA-grown cells suggest that two mechanisms acting simultaneously allow the cells to cope with the large amounts of metal ions taken up together with EDTA. In one mechanism the metal ions are excreted, in the other they are inactivated intracellularly in polyphosphate granules.

Keywords: transport, EDTA, ${ }^{45} \mathrm{Ca}^{2+}$, speciation, EDX analysis

\section{INTRODUCTION}

EDTA is a compound belonging to the group of aminopolycarboxylic acids which forms strong complexes with di- and trivalent metal ions. For that

Abbreviations: CCCP, carbonyl cyanide $m$-chlorophenylhydrazone; DCCD, $N, N^{\prime}$-dicyclohexylcarbodiimide; 2,4-DNP, 2,4-dinitrophenol; DTPA, diethylenetriaminepentaacetate; ED3A, ethylenediaminetriacetate; EDDA, ethylenediaminediacetate; EDDS, ethylenediaminedisuccinate; EDX, electron-dispersive X-ray; FCCP, carbonyl cyanide $p$-(trifluoromethoxy)phenylhydrazone; HEDTA, $N$-(2-hydroxyethyl)ethylenediaminetriacetate; IDA, iminodiacetate; NTA, nitrilotriacetate. reason, EDTA is employed in various industrial processes and products to prevent unwanted reactions of metal ions. Worldwide, it is one of the most extensively used synthetic sequestering agents. Since most of its applications are water-based, EDTA is normally disposed of in waste water and consequently enters wastewater treatment plants. Elimination of EDTA from waste water is negligible during normal treatment (Lahl \& Burbaum, 1988; Alder et al., 1990; Kari \& Giger, 1996). As a result, EDTA is released into surface waters, where it occurs in concentrations ranging from about 5 to $50 \mu \mathrm{g} \mathrm{l}^{-1}$ (Klopp \& Pätsch, 1994; Houriet, 1996; Kari, 1994). In surface waters, the only efficient process for the 
removal of EDTA is decomposition of the photolabile EDTA species, Fe(III)EDTA, by sunlight (Frank \& Rau, 1989; Kari et al., 1995; Kari \& Giger, 1995). Although biodegradation of EDTA seems to be of minor importance in the environment, Gram-negative bacterial strains that are able to grow with EDTA as the sole source of carbon, nitrogen and energy have been isolated. An Agrobacterium species was reported to grow only with $\mathrm{Fe}$ (III)EDTA (Lauff et al., 1990; Palumbo et al., 1994), whereas another bacterial isolate, strain BNC1, grew with EDTA in the presence of $\mathrm{Ca}^{2+}$ or $\mathrm{Mg}^{2+}$ but was incapable of utilizing uncomplexed or $\mathrm{Fe}^{3+}$-complexed EDTA (Nörtemann, 1992; Henneken et al., 1995). Recently, a third strain, DSM 9103, was isolated in our laboratory (Witschel et al., 1997) starting from an EDTA-degrading mixed culture enriched by Gschwind (1992). According to the $16 \mathrm{~S}$ rRNA gene sequence, strain DSM 9103 is located in the Rhizobium Agrobacterium branch within the $\alpha$-subclass of the Proteobacteria (Witschel et al., 1995) but further characterization is needed to establish its exact taxonomic position.

Up to now, information on the biochemistry of EDTA degradation is confined to the first two catabolic steps as analysed in cell extracts of strain BNC1 (Klüner et al., 1998; Payne et al., 1998) and strain DSM 9103 (Witschel et al., 1997). A monooxygenase was shown to catalyse the first attack on EDTA, with the oxidative removal of two acetyl groups from the molecule (Witschel et al., 1997). This strongly suggests that EDTA enters the cell in an unmodified form. However, it is currently not known how EDTA is transported into cells of EDTAdegrading bacteria. In this paper we report the first studies on EDTA uptake into whole cells of strain DSM 9103. Since EDTA is always complexed with di- or trivalent metal ions in the environment (Nowack, 1996), the role of metal ions in the transport of this complexing agent has been given special attention.

\section{METHODS}

Chemicals. Carboxy-labelled $\left[{ }^{14} \mathrm{C}\right] \mathrm{EDTA}$ with a specific activity of $6.7 \mathrm{mCi} \mathrm{mmol}^{-1}\left(0.25 \mathrm{MBq}^{2} \mathrm{~mol}^{-1}\right)$ was purchased from Sigma. ${ }^{45} \mathrm{Ca}^{2+}$ in the form of $\mathrm{CaCl}_{2}$ with a specific activity of $35 \mathrm{mCi} \mathrm{mg} \mathrm{mg}^{-1}\left(1.29 \mathrm{MBq} \mathrm{\mu g}^{-1}\right) \mathrm{Ca}^{2+}$ was obtained from Amersham. (S,S)-ethylenediaminedisuccinate [(S,S)-EDDS] was a gift from Ciba Chemikalien and ethylenediaminetriacetate (ED3A), $N, N^{\prime}$-ethylenediaminediacetate $\left(N, N^{\prime}\right.$ EDDA) and $N, N$-EDDA were gifts from BASF. All other chemicals were of analytical grade and were purchased from either Fluka or Merck.

Growth of micro-organisms. The EDTA-degrading strain DSM 9103 was grown in continuous culture at a dilution rate of $0.025 \mathrm{~h}^{-1}$ in a mineral salt medium (Egli et al., 1988) containing $1.5 \mathrm{~g}^{\mathrm{EDTA}} \mathrm{I}^{-1}$ as the sole source of carbon, nitrogen and energy. EDTA was added as the tetrasodium salt; in the medium it was mainly complexed with $\mathrm{Ca}^{2+}$ and $\mathrm{Mg}^{2+}$ as inferred from equilibrium calculations performed with the computer program ChemEQL (Müller, 1996). The $\mathrm{pH}$ was maintained at $\mathrm{pH} 7 \cdot 0$ by automatic addition of $\mathrm{H}_{3} \mathrm{PO}_{4}$ $(1.0 \mathrm{M})$ and the temperature was maintained at $30^{\circ} \mathrm{C}$. To test EDTA uptake of cells grown with substrates other than
EDTA, strain DSM 9103 was cultivated in batch culture with the same mineral medium as described above but with only $1 \mathrm{~g}$ substrate added per litre. In the case of fumarate, $\mathrm{NH}_{4} \mathrm{Cl}(0.5 \mathrm{~g}$ $\mathrm{l}^{-1}$ ) was included in the mineral medium as a nitrogen source.

Preparation of cells for uptake assays. Cells from $50 \mathrm{ml}$ of either chemostat or batch culture were harvested by centrifugation $\left(15 \mathrm{~min}, 4^{\circ} \mathrm{C}, 7500 \mathrm{~g}\right)$, washed three times with a phosphate buffer consisting of $2.3 \mathrm{mM} \mathrm{Na} \mathrm{HPO}_{4}, 1.91 \mathrm{mM}$ $\mathrm{KH}_{2} \mathrm{PO}_{4}$ and $2.7 \mathrm{mM} \mathrm{CaCl}{ }_{2}$, adjusted to $\mathrm{pH} 7 \cdot 0$. The buffer composition was derived from the growth medium by omitting EDTA, trace elements and $\mathrm{MgSO}_{4}$. When the influence of metal ions was investigated, the phosphate buffer was replaced by a $0.05 \mathrm{M}$ HEPES buffer, $\mathrm{pH} 7 \cdot 0$. Since the action of valinomycin and nigericin depends on high $\mathrm{K}^{+}$concentrations (Konings et al., 1981), a phosphate buffer containing $20 \mathrm{mM}$ $\mathrm{Na}_{2} \mathrm{HPO}_{4}, 20 \mathrm{mM} \mathrm{KH}_{2} \mathrm{PO}_{4}$ and $0.5 \mathrm{mM} \mathrm{CaCl}_{2}$ was employed for testing the effect of these inhibitors. This buffer was also used for the determination of $\mathrm{pH}$ and temperature optima. The cell pellet obtained after the last washing step was resuspended in 1-2 $\mathrm{ml}$ of the buffer that had already been used for washing and was kept on ice for the duration of the experiment.

Measurement of $\left[{ }^{14} \mathrm{C}\right]$ EDTA transport. Uptake of $\left[{ }^{14} \mathrm{C}\right]$ EDTA was assayed by a rapid filtration method. Cells were suspended in $2 \mathrm{ml}$ of one of the above-mentioned buffers to a final $\mathrm{OD}_{546}$ of 0.25 or $1.0\left[\mathrm{OD}_{546}\right.$ was measured with $1 \mathrm{~cm}$ cuvettes in a Uvikon 860 spectrophotometer (Kontron)]. The suspension was incubated for $5 \mathrm{~min}$ at $30{ }^{\circ} \mathrm{C}$ before the $\left[{ }^{14} \mathrm{C}\right] \mathrm{EDTA}$ was added to start the uptake experiment. Aliquots of $200 \mu \mathrm{l}$ were withdrawn from the assay mixture at various times and immediately filtered through cellulose nitrate filters with a pore size of $0.45 \mu \mathrm{m}$ (Sartorius). The filters were immediately washed with $5 \mathrm{ml}$ phosphate or HEPES buffer containing $50 \mu \mathrm{M}$ unlabelled EDTA. Then the filters were placed in scintillation vials and $3 \mathrm{ml}$ scintillation liquid (FilterCount, Packard Instrument) was added. Finally, the radioactivity was determined with a BETAmatic I liquid scintillation counter (Kontron Analytical). All uptake activities given in the Results are mean values of two or three independent transport assays.

Measurement of ${ }^{45} \mathrm{Ca}^{2+}$ uptake. As in the case of $\left[{ }^{14} \mathrm{C}\right] \mathrm{EDTA}$, ${ }^{45} \mathrm{Ca}^{2+}$ uptake was determined by the rapid filtration method using cells grown in continuous culture and washed three times with 0.05 M HEPES buffer, $\mathrm{pH} 7 \cdot 0$. The assay procedure was in all points identical to that employed for measuring $\left[{ }^{14} \mathrm{C}\right]$ EDTA uptake, except for the washing of filters. To remove ${ }^{45} \mathrm{Ca}^{2+}$ adsorbed to the cell surface, the filters were first washed with $15 \mathrm{ml}$ HEPES buffer containing $10 \mathrm{mM} \mathrm{CaCl}$, and then with $25 \mathrm{ml}$ of the same buffer but containing $0.5 \mathrm{M}$ $\mathrm{CaCl}_{2}$. Scintillation counting was performed with a Tri-Carb $2200 \mathrm{Ca}$ liquid scintillation analyser (Packard Instruments).

Analytical procedures. The ATP content of whole cells was analysed with the Bioluminescence Assay Kit HSII (Boehringer Mannheim). Luminescence was measured with a Bertholdtype microplate luminometer LB-96-P. Protein concentrations of cell suspensions were determined as described by Bradford (1976) after boiling the cells for $15 \mathrm{~min}$ in $0 \cdot 1 \mathrm{M} \mathrm{NaOH}$.

Electron microscopic study of cells of strain DSM 9103. DSM 9103 cells were fixed by adding glutaraldehyde $(2 \%$ final concentration) to the culture medium. After fixation for $2 \mathrm{~h}$ at room temperature, the cells were washed once with tap water. After centrifugation, the cell pellet was embedded in lowgelling-temperature agarose (Sea Plaque; FMC). The parts containing the cell pellet were cut from the gel block and further processed as tissue blocks. For structural analysis, these blocks were postfixed for $2 \mathrm{~h}$ at $4{ }^{\circ} \mathrm{C}$ using $1 \% \mathrm{OsO}_{4}$ in 
$0.05 \mathrm{M}$ cacodylate buffer $(\mathrm{pH} 7 \cdot 5)$. After dehydration with ethanol and acetone the specimen was embedded in Epon/ Araldite. Sections were stained with uranyl acetate $(5 \mathrm{~min})$ and lead citrate $(5 \mathrm{~min})$ according to the method described by Reynolds (1963). Photographs were taken with an EM 301 electron microscope (Philips Electronic Optics). For electrondispersive $\mathrm{X}$-ray (EDX) analysis, fixation with $\mathrm{OsO}_{4}$ was omitted. Sections were mounted on carbon-coated gold grids and analysed without poststaining. Direct EDX analysis of whole cells was done on bacteria that had been washed twice with distilled water and dried onto carbon-coated gold grids. The EDX analysis was performed with a Philips CM 12 scanning transmission electron microscope equipped with an EDAX DX-4 analyser (Philips Electronic Optics).

\section{RESULTS}

\section{Uptake of $\left[{ }^{14} \mathrm{C}\right]$ EDTA by EDTA-grown cells}

Since in the growth medium, EDTA is mainly complexed with $\mathrm{Ca}^{2+}$ and $\mathrm{Mg}^{2+}$, three buffer systems were tested for their influence on EDTA uptake (phosphate buffer plus $\mathrm{Mg}^{2+}$ and $\mathrm{Ca}^{2+}$, and phosphate buffer plus either $\mathrm{Ca}^{2+}$ or $\mathrm{Mg}^{2+}$ ). In all cases, DSM 9103 cells grown in continuous culture with EDTA as the sole source of carbon, nitrogen and energy rapidly accumulated radioactivity from ${ }^{14} \mathrm{C}$-labelled EDTA. Uptake was linear for several minutes. Since uptake assays in the presence of $\mathrm{Ca}^{2+}$ only gave slightly better results than the other two buffers, the $\mathrm{Ca}^{2+}$-containing phosphate buffer was employed for transport studies. Cells that had been treated with heat $\left(20 \mathrm{~min}, 80^{\circ} \mathrm{C}\right)$ or $3.7 \%$ formaldehyde did not transport EDTA, or only at a very low level (Fig. 1). Preincubation of the cells for $10 \mathrm{~min}$ in the presence of $8 \mathrm{mM}$ fumarate or $0.02 \times$ nutrient broth before

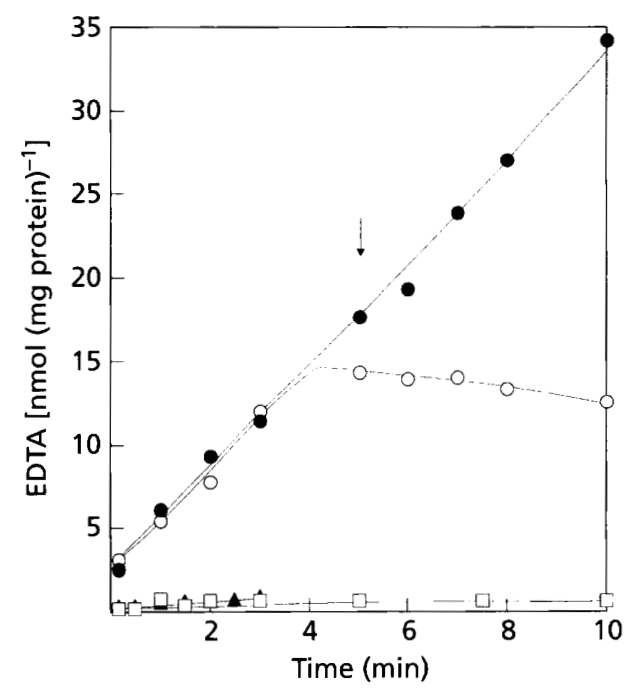

Fig. 1. Incorporation of EDTA by EDTA-grown cells of DSM 9103. O. Uptake of $\left[{ }^{14} \mathrm{C}\right]$ EDTA $(10.4 \mu \mathrm{M}$ final concentration in the assay) by cells grown with EDTA in continuous culture; $O$, effect of addition of $1 \mathrm{mM}$ (final concentration) unlabelled EDTA (arrow) after $5 \mathrm{~min}$ incubation with $\left[{ }^{14} \mathrm{C}\right] \mathrm{EDTA}$. Uptake of EDTA by cells inactivated either by heat $(\square)$ or by formaldehyde $(\boldsymbol{\Delta})$ is also shown. addition of labelled EDTA had no effect on EDTA uptake.

Radioactivity from $\left[{ }^{14} \mathrm{C}\right]$ EDTA that had been accumulated over an incubation period of $5 \mathrm{~min}$ was not released significantly after the addition of a 100 -fold excess of unlabelled EDTA to the assay mixture. However, further incorporation of radioactivity stopped immediately (Fig. 1). Apparently, intracellularly accumulated radioactivity from $\left[{ }^{14} \mathrm{C}\right]$ EDTA cannot be exchanged for unlabelled EDTA, suggesting a rapid degradation of EDTA and/or incorporation into biomass. The slight decrease of radioactivity measured after the addition of unlabelled EDTA can be attributed to a release of ${ }^{14} \mathrm{CO}_{2}$ (not tested) as a result of dissimilation.

Cells grown in the chemostat at $D=0.025 \mathrm{~h}^{-1}$ with EDTA/mineral salts medium exhibited approximately double the rate of uptake compared to cells collected from the mid-exponential phase of batch cultures cultivated with EDTA as the only source of carbon, nitrogen and energy. Therefore, uptake assays were performed with cells from continuous culture, except for experiments in which the influence of different growth substrates on transport activities was tested.

The optimum temperature for transport was $40^{\circ} \mathrm{C}$. At 20 and $45^{\circ} \mathrm{C}$ the uptake rates were less than $50 \%$ of the maximum rate. In the presence of $\mathrm{Ca}^{2+}$, the $\mathrm{pH}$ optimum of EDTA uptake was found to be $\mathrm{pH} 7 \cdot 0$. At lower $\mathrm{pH}$ values, EDTA uptake was only slightly reduced: $70 \%$ of the maximum uptake rate was still found at $\mathrm{pH} 5 \cdot 0$. On the other hand, at more alkaline $\mathrm{pH}$ values, the transport activities dropped drastically. At $\mathrm{pH} 8.0$ and 9.0 only $50 \%$ and $6 \%$, respectively, of the maximum uptake rate were measured (Fig. 2a). When $\mathrm{Ca}^{2+}$ was omitted from the buffer, EDTA was no longer complexed with metal ions, resulting in a shift of the $\mathrm{pH}$ optimum for EDTA uptake to $\mathrm{pH} 6 \cdot 0$. Moreover, in the absence of $\mathrm{Ca}^{2+}$ about $90 \%$ of the maximum uptake rate was still observed at $\mathrm{pH} 5 \cdot 0$. At $\mathrm{pH} 7 \cdot 0$ and $8 \cdot 0$ only $70 \%$ and $40 \%$, respectively, of the optimal transport activity were detected and at $\mathrm{pH} 9 \cdot 0$ EDTA uptake was negligible (Fig. 2b). Of course, the speciation of EDTA depends on both the $\mathrm{pH}$ value and the presence or absence of $\mathrm{Ca}^{2+}$ (Fig. 2). The fact that a shift in the $\mathrm{pH}$ optimum was observed when $\mathrm{Ca}^{2+}$ was omitted suggests that there is not only an optimum $\mathrm{pH}$ for EDTA transport activity but that the speciation of EDTA also has a marked effect on uptake activity.

\section{Dependence of EDTA uptake on the growth substrate}

Tests for EDTA uptake were performed with cells grown in batch culture with EDTA, nitrilotriacetate (NTA), iminodiacetate (IDA), with (S,S)-EDDS, a structural isomer of EDTA, or with fumarate plus $\mathrm{NH}_{4}^{+}$. Cells cultivated with EDTA or NTA exhibited the highest EDTA uptake activities, (S,S)-EDDS-grown cells showed intermediate activities and bacteria grown with 

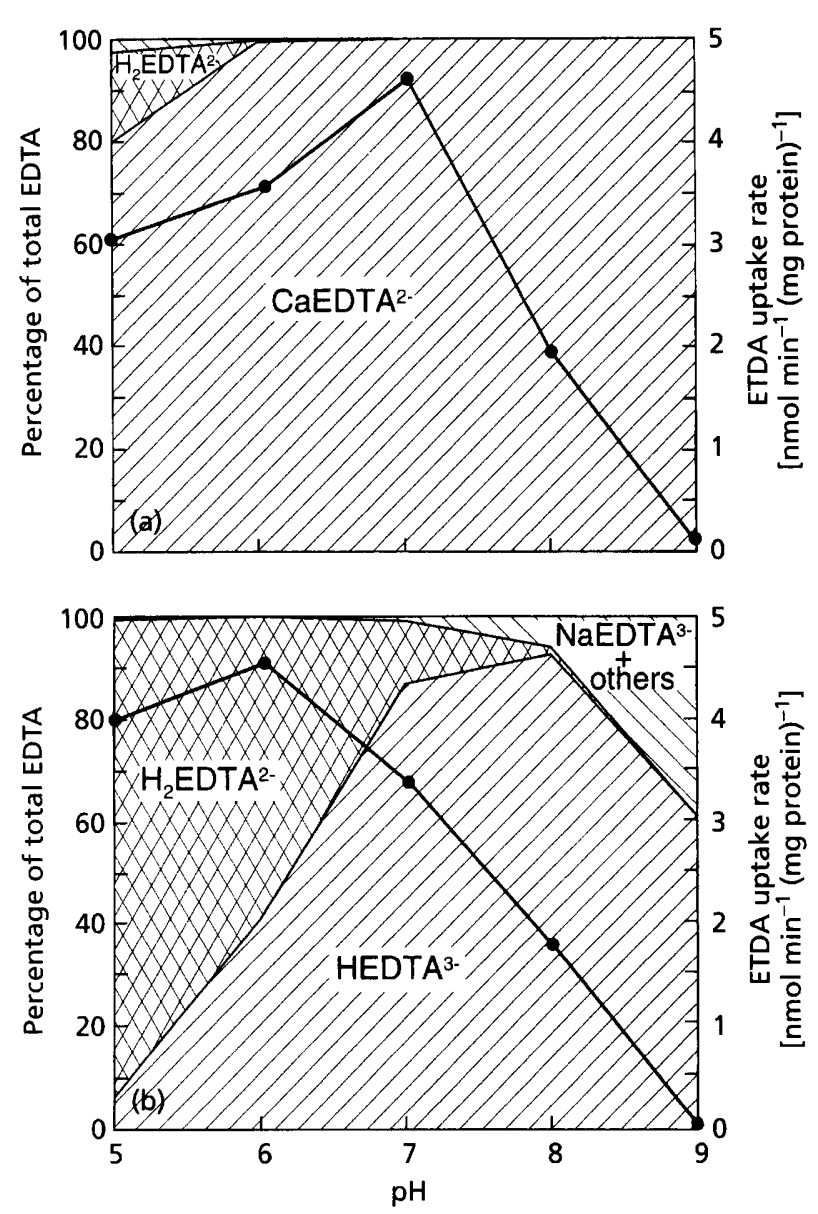

Fig. 2. Influence of $\mathrm{pH}$ on initial EDTA-uptake rates in the presence (a) or absence (b) of $\mathrm{Ca}^{2+}$. In addition to the measured initial EDTA-uptake rates (O), the most important EDTA species present in the assay mixtures are shown.

IDA or fumarate transported EDTA at rates that were about ten times lower than those of EDTA-grown cells (Table 1). In the case of NTA-grown cells, a significant reduction of EDTA uptake was observed when both $\left[{ }^{14} \mathrm{C}\right]$ EDTA and a 100 -fold excess of NTA were added to the assay mixture. No such effect was found for $(\mathrm{S}, \mathrm{S})$ EDDS-grown cells in a similar experiment in which NTA was replaced by (S,S)-EDDS (Table 1).

\section{Kinetics of EDTA uptake}

Kinetic parameters of CaEDTA transport were determined from initial (between 10 and $45 \mathrm{~s}$ ) uptake rates by cell suspensions at an $\mathrm{OD}_{546}$ of approximately 0.25 and with $\left[{ }^{14} \mathrm{C}\right]$ EDTA concentrations ranging from $0 \cdot 1$ to $83 \mu \mathrm{M}$. Between $0 \cdot 1$ and $5 \mu \mathrm{M}$ the initial uptake rate increased with increasing EDTA concentrations (data not shown). For higher EDTA concentrations the transport activity remained constant. A double-reciprocal plot of the data indicated an apparent $K_{\mathrm{t}}$ of $0.39 \pm 0.06 \mu \mathrm{M}$ and a $V_{\max }$ of $8.6 \pm 1.0 \mathrm{nmol} \mathrm{min}{ }^{-1}(\mathrm{mg}$ protein $)^{-1}$. The EDTA uptake rates of fumarate-grown cells as a function of the EDTA concentrations between 10.4 and $207 \mu \mathrm{M}$ showed no increase and were more than tenfold lower than the comparable data obtained with EDTA-grown cells. Thus, diffusion seems to be of no importance for EDTA uptake.

\section{Effect of metabolic inhibitors on EDTA uptake}

Preliminary experiments with $\mathrm{KCN}$ indicated that EDTA uptake is energy-dependent. Uptake of EDTA (final concentration $10.4 \mu \mathrm{M}$ ) was totally inhibited in the presence of $10 \mathrm{mM} \mathrm{KCN}$ and at $1 \mathrm{mM} \mathrm{KCN}$ only $8 \%$ of the original transport activity was measured. To study the energy dependence of EDTA transport in more detail, the effects of different inhibitors of energy metabolism on EDTA uptake and internal ATP content were determined. The uncouplers 2,4-dinitrophenol (2,4-DNP), carbonyl cyanide $m$-chlorophenylhydrazone (CCCP) and carbonyl cyanide $p$-(trifluoromethoxy)phenylhydrazone (FCCP) can dissipate the proton-motive force, i.e. both the electrical potential $(\Delta \psi)$ and the $\mathrm{pH}$ gradient $(\Delta \mathrm{pH})$ across the cell membrane. Pre-

Table 1. EDTA-uptake rate of strain DSM 9103 cells grown in batch culture with different growth substrates

In the assay mixture the initial $\left[{ }^{14} \mathrm{C}\right]$ EDTA concentration was $10 \cdot 4 \mu \mathrm{M}$ and the $\mathrm{OD}_{546}$ of the cell suspension was $1 \cdot 0$. NA, Not applicable; ND, not determined.

\begin{tabular}{|lccc|}
\hline $\begin{array}{l}\text { Growth } \\
\text { substrate }\end{array}$ & $\begin{array}{c}\text { EDTA } \\
\text { uptake rate }\end{array}$ & $\begin{array}{c}\text { Activity as percentage } \\
\text { of that with EDTA- } \\
\text { grown cells }\end{array}$ & $\begin{array}{c}\text { EDTA uptake rate with 100-fold } \\
\text { excess of the growth substrate* }\end{array}$ \\
\hline EDTA & $3 \cdot 8$ & 100 & NA \\
Fumarate & $0 \cdot 42$ & 11 & $0 \cdot 34$ \\
IDA & 0.5 & 98 & 1.28 \\
NTA & 3.71 & 49 & 1.66 \\
(S,S)-EDDS & $1 \cdot 87$ & 98 \\
\hline
\end{tabular}

* nmol $\min ^{-1}$ (mg protein) $)^{-1}$. 
Table 2. Effect of different inhibitors on $\left[{ }^{14} \mathrm{C}\right]$ EDTA uptake and intracellular ATP levels in EDTA-grown DSM 9103 cells

\begin{tabular}{|c|c|c|c|c|}
\hline Inhibitor & Mode of action & Concn $(\mu \mathrm{M})$ & $\begin{array}{c}\text { EDTA } \\
\text { uptake* }\end{array}$ & $\begin{array}{l}\text { Internal ATP } \\
\text { level* }\end{array}$ \\
\hline 2,4-DNP & Protonophore, uncoupler & 125 & 41 & 38 \\
\hline СССР & Protonophore, uncoupler & $12 \cdot 5$ & 13 & 40 \\
\hline FCCP & Protonophore, uncoupler & $12 \cdot 5$ & 14 & 32 \\
\hline DCCD & ATPase inhibitor & 125 & 8 & 32 \\
\hline Valinomycin & $\begin{array}{l}\text { Ionophore, dissipates } \Delta \psi, \Delta \mathrm{pH} \\
\text { remains constant }\end{array}$ & 25 & 90 & 95 \\
\hline Nigericin & $\begin{array}{l}\text { Ionophore, dissipates } \Delta \mathrm{pH}, \Delta \psi \\
\text { remains constant }\end{array}$ & 25 & 28 & 91 \\
\hline Valinomycin + nigericin & Uncoupler & 25 each & 22 & 65 \\
\hline
\end{tabular}

*Shown as the percentage of the control value. In the absence of inhibitor the EDTA uptake rate was $6.1 \pm 1.2 \mathrm{nmol} \min ^{-1}$ (mg protein) $)^{-1}$ and the ATP concentration in the cell suspension was $0.048 \pm 0.009 \mu \mathrm{M}$. These values were taken as $100 \%$.

Table 3. Uptake of different metal-EDTA species by EDTA-grown cells of strain DSM 9103

For comparison, the monooxygenase-catalysed degradation of the complexes is also shown. ND, Not determined.

\begin{tabular}{|c|c|c|c|c|}
\hline EDTA species & $\log K_{\text {MeEDTA }} *$ & $\begin{array}{l}\text { Transport rate }[\mathrm{nmol} \\
\left.\min ^{-1}(\mathbf{m g} \text { protein })^{-1}\right]\end{array}$ & $\begin{array}{c}\text { Activity } \\
\text { (percentage of that } \\
\text { with CaEDTA) }\end{array}$ & $\begin{array}{l}\text { Enzymic degradation of } \\
\text { EDTA (percentage of } \\
\text { activity with MgEDTA) } t\end{array}$ \\
\hline Free EDTA & & $6 \cdot 16$ & 96 & 0 \\
\hline BaEDTA & $7 \cdot 8$ & $6 \cdot 2$ & 97 & $\mathrm{ND}$ \\
\hline MgEDTA & $8 \cdot 83$ & 5.69 & 89 & 100 \\
\hline CaEDTA & $10 \cdot 61$ & $6 \cdot 39$ & 100 & 0 \\
\hline MnEDTA & $13 \cdot 81$ & $3 \cdot 34$ & 52 & 35 \\
\hline CoEDTA & $16 \cdot 26$ & 0 & 0 & 19 \\
\hline ZnEDTA & $16 \cdot 44$ & 0 & 0 & 53 \\
\hline NiEDTA & $18 \cdot 25$ & 0 & 0 & 0 \\
\hline CuEDTA & 18.7 & 0 & 0 & 11 \\
\hline $\mathrm{Fe}(\mathrm{III}) \mathrm{EDTA}$ & 25 & 0 & 0 & 0 \\
\hline
\end{tabular}

* Stability constants were taken from Martell \& Smith (1974).

† Data taken from Witschel et al. (1997). Highest enzymic activity of $1.68 \mu \mathrm{mol} \mathrm{min}^{-1}$ (mg protein) ${ }^{-1}$ was measured for MgEDTA.

incubation with these compounds inhibited EDTA uptake significantly (Table 2), whereas the ionophore valinomycin, which dissipates $\Delta \psi$ only while $\Delta \mathrm{pH}$ remains unaffected, had almost no effect on EDTA uptake. In contrast, addition of the ionophore nigericin, which dissipates $\Delta \mathrm{pH}$, led to a markedly reduced EDTAtransport activity. A combination of both ionophores acts as an uncoupler, destroying the proton-motive force. The combined inhibiting effect was similar to that of the other uncouplers tested (Table 2). Addition of the ATPase inhibitor, $N, N^{\prime}$-dicyclohexylcarbodiimide (DCCD), had the most pronounced inhibitory effect on EDTA uptake. In the presence of either uncouplers or DCCD the cellular ATP level was decreased to about $30-40 \%$ of the control. In contrast, addition of one of the two ionophores tested had only a slight effect on the internal ATP level (Table 2). Nevertheless, in the presence of nigericin, EDTA uptake was greatly reduced despite the high ATP level. Taken together, there is apparently no correlation between EDTA transport activity and intracellular ATP content.

The effect of the ionophores on EDTA uptake was also investigated as a function of $\mathrm{pH}$ between $\mathrm{pH} 5.0$ and pH 9.0 in the presence of $\mathrm{Ca}^{2+}$ ions. In the case of nigericin, EDTA transport was always very low. The pattern for valinomycin was similar to that seen in the absence of inhibitor, i.e. a maximum uptake rate at $\mathrm{pH}$ $7 \cdot 0$, drastic decrease at more alkaline $\mathrm{pH}$ values, and slight decrease at more acidic conditions (data not shown). These data suggest that EDTA transport is driven by the proton gradient. 

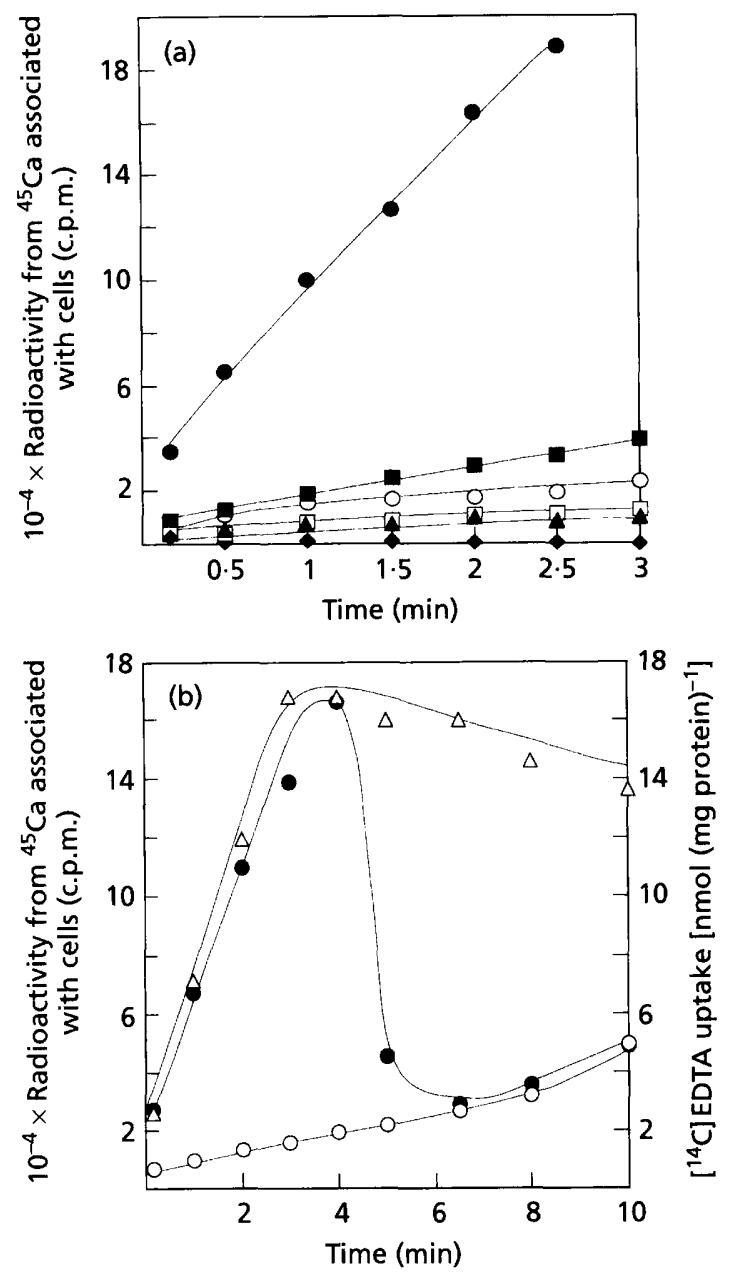

Fig. 3. Incorporation of radioactivity from ${ }^{45} \mathrm{Ca}^{2+}$ by EDTA- or fumarate-grown DSM 9103 cells over a time period of $3 \mathrm{~min}$ (a) or $10 \mathrm{~min}$ (b). The protein concentration in the assay was $0.12 \mathrm{mg} \mathrm{ml}^{-1}$ and the ${ }^{45} \mathrm{Ca}^{2+}$ concentration was $10.5 \mu \mathrm{M}$. The complexing agents were present at a concentration of $10.4 \mu \mathrm{M}$. (a) ${ }^{45} \mathrm{Ca}^{2+}$ uptake of EDTA-grown cells in the presence (O) or absence $(O)$ of stoichiometric amounts of EDTA, as well as in the presence of HEDTA $(\boldsymbol{A})$ or DTPA $(\Delta)$. The incorporation of ${ }^{45} \mathrm{Ca}^{2+}$ by formaldehyde-treated, EDTA-grown cells $(\square)$ and by fumarate-grown cells ( $\square$ ) is also given. (b) ${ }^{45} \mathrm{Ca}^{2+}$ uptake in the presence (O) or absence $(O)$ of EDTA and the incorporation of ${ }^{14} \mathrm{C}$-labelled EDTA $(\triangle)$. The latter was measured in a separate transport experiment in the presence of equimolar amounts of unlabelled $\mathrm{Ca}^{2+}$ using the same cell suspension as for ${ }^{45} \mathrm{Ca}^{2+}$ uptake.

\section{Effect of structurally related compounds on EDTA uptake}

$\left[{ }^{14} \mathrm{C}\right] \mathrm{EDTA}$ uptake rates were determined at an initial EDTA concentration of $10.4 \mu \mathrm{M}$ in the presence of either a 10- or 100-fold excess of structurally related compounds [diethylenetriaminepentaacetate (DTPA), N-(2-hydroxyethyl)ethylenediaminetriacetate (HEDTA), NTA, IDA, (S,S)-EDDS, 1,3-diaminopropanetetraacetate, ED3A, $N, N^{\prime}$-EDDA, $N, N$-EDDA, citrate, glutamate, or aspartate]. Since most of the compounds tested are also powerful complexing agents, sufficient $\mathrm{Ca}^{2+}$ was added to the assay mixture to ensure virtually complete complexation of both EDTA and the test compound. At 10-fold excesses of related compounds no significant effects were detected. Only in the case of DTPA was there a slight reduction, $30 \%$, of EDTA uptake. This effect was much more pronounced at a 100-fold excess of DTPA. Addition of the other compounds at a 100 -fold excess did not result in a drastic reduction of EDTA transport. However, in the presence of ED3A and HEDTA, weak inhibition of EDTA uptake could be measured. It is noteworthy that the four naturally occurring compounds [citrate, aspartate, glutamate and (S,S)-EDDS], had no inhibitory effect on EDTA uptake. The last compound is produced by some actinomycetes, presumably to stimulate the uptake of $\mathrm{Zn}^{2+}$ (Cebulla, 1995).

The influence of DTPA on EDTA transport was further investigated at DTPA concentrations ranging from $10 \mu \mathrm{M}$ to $5 \mathrm{mM}$ and at four different initial EDTA concentrations $(2 \cdot 08,4 \cdot 16,10 \cdot 4$ and $20 \cdot 8 \mu \mathrm{M})$. A graphical representation of the data according to Dixon (1953), i.e. the reciprocal of the uptake rate as a function of the concentration of the inhibitor DTPA, revealed curves that shared a common point of intersection, indicating competitive inhibition. This was supported by the Cornish-Bowden plot (Cornish-Bowden, 1974), where the ratio EDTA concentration/uptake rate is plotted as a function of the DTPA concentration and which revealed parallel lines. Both linearization procedures suggest that DTPA is most likely a competitive inhibitor of EDTA transport with an inhibition constant of approximately $80 \mu \mathrm{M}$.

Interestingly, in cells grown with EDTA, NTA had no influence on EDTA uptake even at NTA concentrations 1000 -fold higher than the concentration of $\left[{ }^{14} \mathrm{C}\right] \mathrm{EDTA}$. However, in NTA-cultivated cells the addition of NTA resulted in an inhibitory effect on EDTA uptake. When a 50-fold or higher excess of NTA was present, EDTA uptake was reduced by a factor of 5-10.

\section{Uptake of EDTA in the presence of di- and trivalent metal ions}

EDTA forms strong complexes with di- and trivalent metal ions and we therefore investigated whether EDTA uptake is affected by various metal ions. To ensure metal complexation of most of the EDTA, the metal ions, as chloride salts, were added in a slight excess over EDTA (i.e. metal ion concentration of $12.5 \mu \mathrm{M}$ and EDTA concentration of $10.4 \mu \mathrm{M}$ ), and both components were mixed for at least $20 \mathrm{~h}$ before use. All experiments were performed in HEPES buffer because this buffer exhibits no metal-complexing capacity. Uncomplexed EDTA or EDTA chelated to $\mathrm{Mg}^{2+}, \mathrm{Ba}^{2+}$ or $\mathrm{Ca}^{2+}$ were taken up at similar rates. With MnEDTA this rate was reduced to about $50 \%$ of the maximum transport rate. In the presence of the other metal ions tested, EDTA was not incorporated by the cells (Table 3). In a series of control experiments with $10.4 \mu \mathrm{M}\left[{ }^{14} \mathrm{C}\right]$ EDTA and $12.5 \mu \mathrm{M}$ metal ions $\left(\mathrm{Ca}^{2+}, \mathrm{Zn}^{2+}, \mathrm{Co}^{2+}, \mathrm{Cu}^{2+}, \mathrm{Ni}^{2+}\right.$ or $\left.\mathrm{Fe}^{3+}\right)$, only 

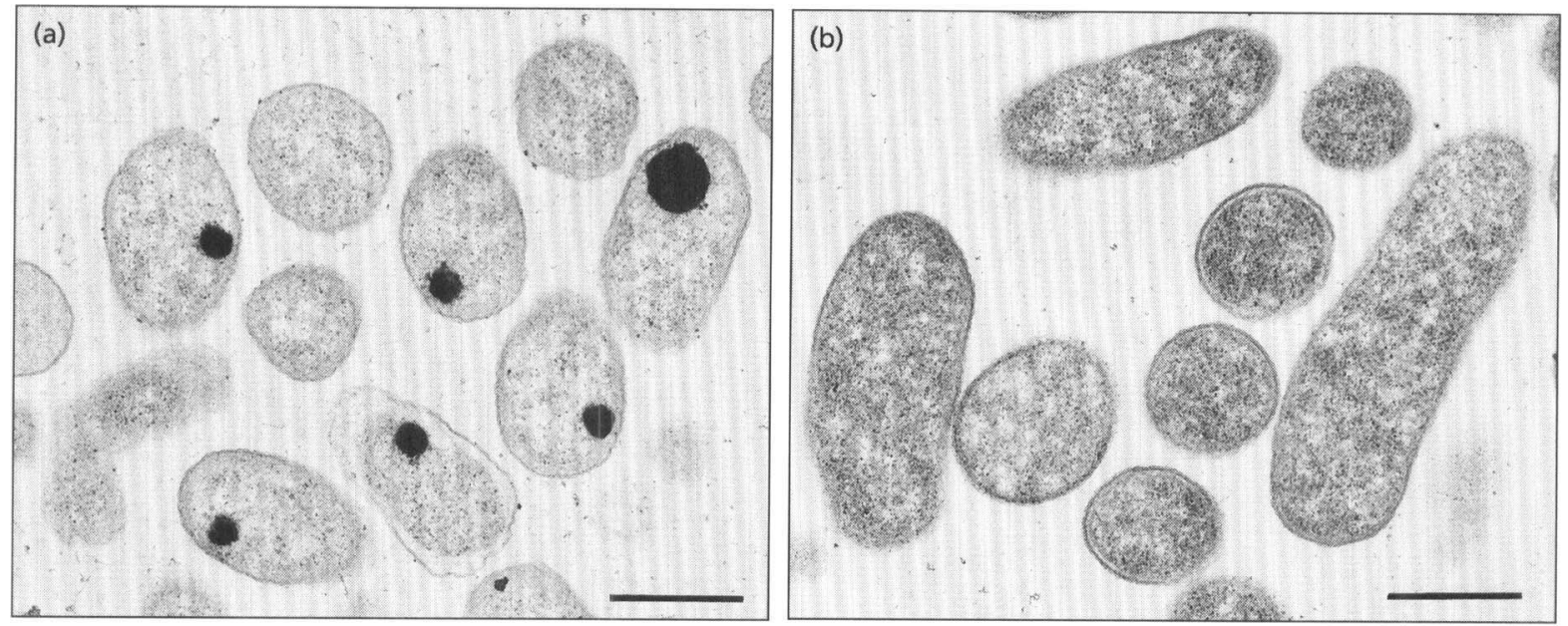

Fig. 4. Thin sections of cells of strain DSM 9103. (a) EDTA-grown cells showing electron-dense inclusion bodies. (b) Fumarate-grown cells. Bars, $0.5 \mu \mathrm{m}$.

the calcium complex was transported. When additional free $\left[{ }^{14} \mathrm{C}\right] \mathrm{EDTA}$ was added after $1 \mathrm{~min}$, the uptake of the excess EDTA was similar to that measured for free and $\mathrm{Ca}^{2+}$-complexed EDTA. These observations suggest that a toxic effect of the metal ions on the cells is unlikely.

\section{Uptake of ${ }^{45} \mathrm{Ca}^{2+}$ in the presence of EDTA}

Free EDTA as well as EDTA complexes with low stability constants seem to be transported easily by whole cells, whereas very stable metal-EDTA complexes were not taken up. Hence, we hypothesized that only free EDTA was transported. This would imply a removal of the metal ions chelated by EDTA prior to uptake. Such a removal would be most probable with complexes of low stability. The presence of a concomitant uptake of calcium and EDTA as a complex was tested with ${ }^{45} \mathrm{Ca}^{2+}$. When cells were incubated with stoichiometric amounts of unlabelled EDTA and ${ }^{45} \mathrm{Ca}^{2+}$, the rate of ${ }^{45} \mathrm{Ca}^{2+}$ uptake was nearly ten times higher than in the absence of EDTA (Fig. 3a). Formaldehydetreated, inactivated cells showed a low ${ }^{45} \mathrm{Ca}^{2+}$ sorption/incorporation rate both in the presence and absence of EDTA. Also, ${ }^{45} \mathrm{Ca}^{2+}$ uptake of uninduced, fumarategrown cells was low in the presence of EDTA. The effect of increased $\mathrm{Ca}^{2+}$ uptake was restricted to the presence of EDTA, whereas other powerful complexing agents, such as HEDTA and DTPA, both of which form strong complexes with $\mathrm{Ca}^{2+}[\log K(\mathrm{CaEDTA})=10 \cdot 61, \log K-$ $($ CaHEDTA $)=8 \cdot 2$ and $\log K(\mathrm{CaDTPA})=10 \cdot 75$; Martell \& Smith (1974)], but are not growth substrates of strain DSM 9103, did not enhance $\mathrm{Ca}^{2+}$ uptake (Fig. 3a). These results suggest that $\mathrm{Ca}$ EDTA is taken up as a complex.

In contrast to the results shown in Fig. 1, in these experiments $\left[{ }^{14} \mathrm{C}\right]$ EDTA incorporation ceased after 3-4 min, presumably because of a changed physiological state of the cells due to prolonged cultivation in continuous culture. Interestingly, as soon as $\left[{ }^{14} \mathrm{C}\right] \mathrm{EDTA}$ incorporation stopped, cell-associated ${ }^{45} \mathrm{Ca}^{2+}$ radioactivity started to decrease rapidly and reached the same final values measured in cells incubated with ${ }^{45} \mathrm{Ca}^{2+}$ but without EDTA (Fig. 3b). Based on a standard curve of c.p.m. as a function of the ${ }^{45} \mathrm{Ca}^{2+}$ concentration, the uptake and release rates of $\mathrm{Ca}^{2+}$ were estimated to be $0.63 \mathrm{nmol} \mathrm{min}{ }^{-1}$ (mg protein) $)^{-1}$ for ${ }^{45} \mathrm{Ca}^{2+}$ incorporation (for the time period between 0 and $3 \mathrm{~min}$ ) in the presence of EDTA, and $-1.83 \mathrm{nmol} \mathrm{min}^{-1}\left(\mathrm{mg}\right.$ protein) ${ }^{-1}$ for the subsequent release of ${ }^{45} \mathrm{Ca}^{2+}$. In contrast, $\left[{ }^{14} \mathrm{C}\right] \mathrm{EDTA}$ was taken up at a rate of $4.99 \mathrm{nmol} \mathrm{min}{ }^{-1}(\mathrm{mg} \text { protein })^{-1}$. The significantly lower $\mathrm{Ca}^{2+}$ uptake rate as compared to $\left[{ }^{14} \mathrm{C}\right]$ EDTA transport indicates that $\mathrm{Ca}^{2+}$ was released simultaneously with its uptake. However, considering a $\mathrm{Ca}^{2+}$ release rate of $-1.83 \mathrm{nmol} \mathrm{min}{ }^{-1}(\mathrm{mg} \text { protein })^{-1}$ during EDTA incorporation, the uptake of $\mathrm{Ca}^{2+}$ was still found to be twofold slower than $\left[{ }^{14} \mathrm{C}\right] \mathrm{EDTA}$ transport, indicating that not only CaEDTA but also free EDTA was taken up by the cells.

\section{Electron-microscopic examination of strain DSM 9103 cells}

Electron micrographs of EDTA-grown cells of strain DSM 9103 revealed dark, round, electron-dense inclusion bodies which were absent in fumarate-grown cells (Fig. 4). EDX analysis of the elemental composition of whole cells indicated the presence of high amounts of phosphorus, magnesium and calcium in the inclusion bodies. In the surrounding cellular area the level of these three elements was much lower (Fig. 5). EDX analysis done on thin sections of EDTA-grown cells gave comparable results (data not shown). However, no enhanced presence of magnesium was found in electrondense zones, whereas an increased content of calcium and phosphorus in these zones was detected. These data 

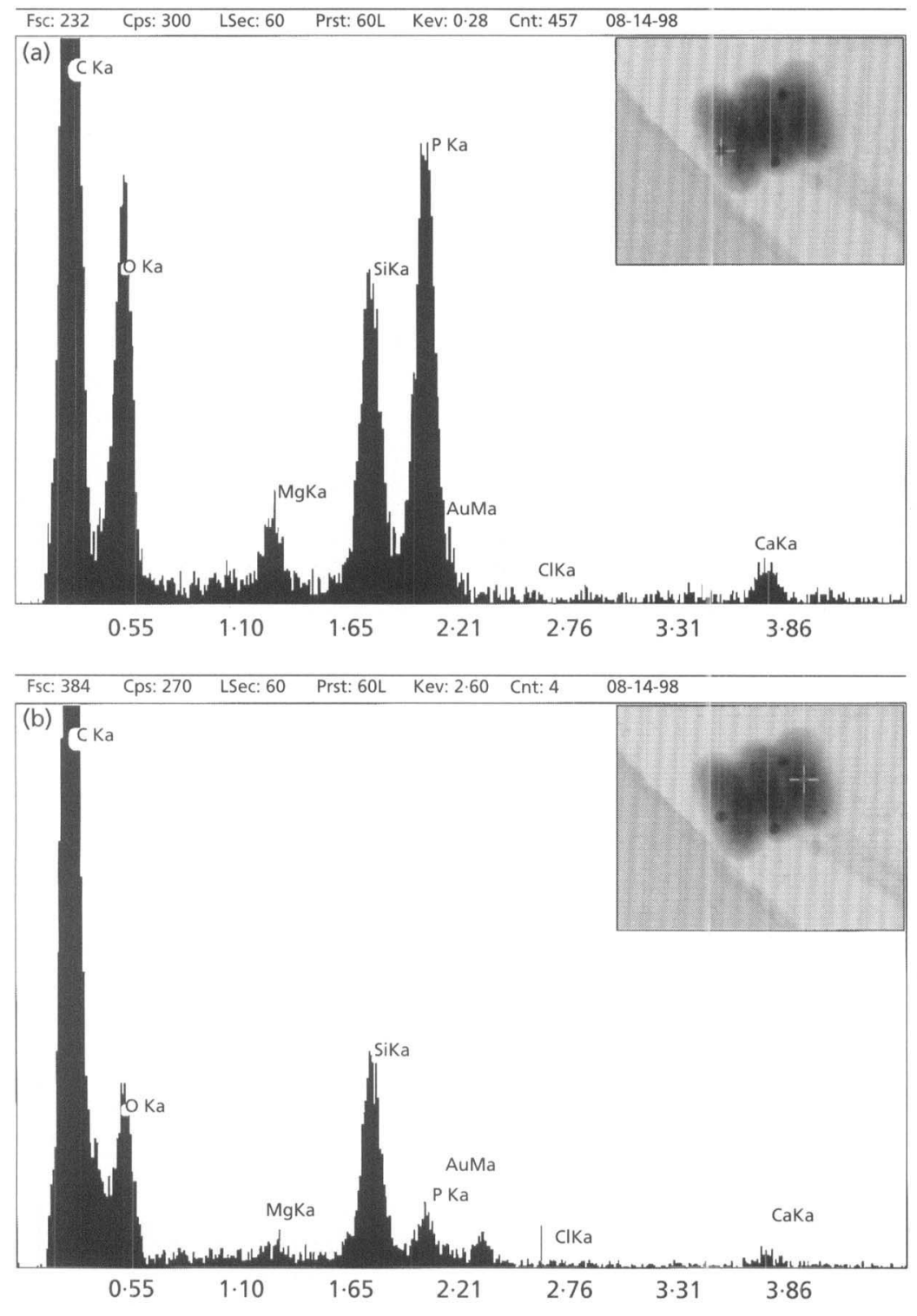

Fig. 5. EDX analysis of whole cells of strain
DSM 9103 grown with EDTA. (a) An X-ray
spectrum obtained with the electron beam
directed to an electron-dense inclusion body
(white cross). The spectrum shows high
levels of phosphorus, magnesium and
calcium. (b) Spectrum obtained when the
electron beam was directed to the
cytoplasm (white cross), showing smaller
amounts of phosphorus, magnesium and
calcium. Moiré-like structures in the centre
of the bacterial cells shown in the insets are
artefacts of digital printing.

are consistent with EDTA-grown strain DSM 9103 cells forming intracellular precipitates consisting of calcium and magnesium phosphates.

\section{DISCUSSION}

\section{Evidence for an active EDTA-transport system}

We have obtained evidence for the existence of a specific, inducible and energy-dependent uptake system for EDTA. (i) The rate of EDTA uptake showed saturation kinetics with a high apparent affinity. (ii) Cells grown with fumarate transported EDTA at a significantly lower rate than EDTA-grown cells. Moreover, no increase of EDTA uptake was observed in fumarategrown cells when they were exposed to $\left[{ }^{14} \mathrm{C}\right] \mathrm{EDTA}$ at concentrations sufficient to saturate the transport system; this argues against a role for diffusion of EDTA into the cell. (iii) EDTA transport was inhibited only by DTPA, a compound closely related to EDTA and not by other related analogues of EDTA. (iv) EDTA uptake was reduced in the presence of uncouplers and of the ionophore nigericin, which dissipates the $\mathrm{pH}$ gradient across the cell membrane, whereas valinomycin, which destroys the electrical gradient, had almost no effect. EDTA uptake thus seems to be driven by the proton gradient. To what extent ATP is also involved in the uptake mechanism cannot be deduced from our data.

To our knowledge, this is the first detailed report of transport of a synthetic complexing agent by bacteria. Preliminary experiments on NTA transport have been performed in an NTA-degrading bacterial mutant (Wong et al., 1973) and in the NTA-degrading Chelatobacter heintzii (Wilberg, 1989). An NTA-uptake mechanism based on an inducible, energy-dependent carrier was proposed. Considering the close similarity of the enzymic breakdown of NTA and EDTA (Uetz et al., 1992; Xu et al., 1997; Witschel et al., 1997), one can speculate that the transport systems for NTA and EDTA 
in C. heintzii and strain DSM 9103 have many characteristics in common.

Comparison of enzymic EDTA degradation (Witschel et al., 1997) and EDTA uptake in strain DSM 9103 cultivated on various substrates reveals similar patterns. Hence, the EDTA transport and degrading enzyme systems are apparently regulated in a coordinated manner. Surprisingly, in NTA-grown cells, EDTA incorporation was inhibited by high NTA concentrations, whereas in EDTA-grown cells this phenomenon was not seen. Thus, NTA was presumably not transported by the EDTA carrier but by a different system. In NTA-grown bacteria, however, the NTAand EDTA-transport systems may compete for energy or a common component, resulting in mutual inhibition. Such common components shared by transport systems for different substances have been described for siderophore uptake in Escherichia coli (Hantke \& Braun, 1975).

\section{Influence of EDTA speciation on transport}

The uptake of different metal-EDTA complexes was found to be strongly dependent on the stability constant of the complexes (Table 3). Only free EDTA and complexes with stability constants lower than $10^{14}$ were taken up by strain DSM 9103. It should be pointed out that no such relationship between stability constant and degradability has been observed for EDTA monooxygenase (Witschel et al., 1997) (Table 3). Similar observations at the whole-cell level and in cell-free extracts have also been made for the EDTA-utilizing strain BNC1 (Klüner et al., 1998). Taken together, these data suggest a strong dependence of the biodegradability of EDTA on its speciation. Based on measurements and equilibrium calculations, Nowack (1996) has determined, for example, the following speciation for the Swiss river Glatt: $31 \% \mathrm{Fe}$ (III)EDTA, $30 \% \mathrm{ZnEDTA}$, $15 \%$ MnEDTA, $12 \%$ CaEDTA, $10 \%$ NiEDTA, $2 \%$ PbEDTA and $0.5 \%$ CuEDTA. Thus, in this river system only about $30 \%$ of the total EDTA (CaEDTA and MnEDTA) would be immediately available to EDTAdegrading bacteria such as strain BNC1 or DSM 9103.

From our data it is not possible to deduce which of the EDTA species is transported by the EDTA carrier. Instead, two mechanisms can be proposed: either (i) the carrier is able to transport all EDTA species which are taken up by whole cells but at different rates, or (ii) only one species can be transported, either free EDTA or one of the metal-EDTA complexes. The latter mechanism would imply that the metal originally complexed with EDTA either has to be removed from the complex or exchanged for the metal in the complex which can be transported by the carrier. Such a mechanism could explain why only complexes with low stability constants are taken up.

Nevertheless, data are available giving an indication of the EDTA species that are transported into cells, i.e. the influence of $\mathrm{pH}$ on EDTA uptake in the presence or absence of $\mathrm{Ca}^{2+}$ (Fig. 2). When $\mathrm{Ca}^{2+}$ was included in the buffer, most of the EDTA was present as a doublenegatively charged $\mathrm{Ca}^{2+}$-complex at all $\mathrm{pH}$ values tested. In this case, the $\mathrm{pH}$ optimum (pH 7.0) for EDTA uptake should not be influenced by the speciation of EDTA. On the other hand, in a buffer devoid of $\mathrm{Ca}^{2+}$ the doublenegatively charged species $\mathrm{H}_{2} \mathrm{EDTA}^{2-}$ is only predominant at the low pH values of 5.0 and 6.0 and it was under these conditions that the highest EDTA uptake rates were measured. At higher $\mathrm{pH}$ values, EDTA was mainly present in the form of HEDTA ${ }^{3-}$. Therefore, doublenegatively charged EDTA species appear to be the form that is transported by the EDTA carrier.

Experiments with ${ }^{45} \mathrm{Ca}^{2+}$ provided an insight into the behaviour of the metal ion during EDTA transport (Fig. $3 a) . \mathrm{Ca}^{2+}$ apparently enters the cells together with EDTA, possibly as a complex, which makes the transport mechanism similar to uptake of the tricarboxylic acid citrate by Bacillus subtilis (Willecke et al., 1973; Bergsma \& Konings, 1983). In whole cells of B. subtilis, the highest citrate uptake rates were measured upon the addition of $\mathrm{Mg}^{2+}$, whereas transport activities in the absence of $\mathrm{Mg}^{2+}$ were approximately ten times lower (Willecke et al., 1973). In experiments with membrane vesicles of B. subtilis (Bergsma \& Konings, 1983) citrate transport was found to be strict in its requirement for divalent cations. In contrast, EDTA transport in strain DSM 9103 was less dependent on the addition of metal ions. However, based on our data we cannot rule out the exclusive uptake of metal-complexed EDTA because of the ability of EDTA to scavenge metal ions from the bacterial surface (Ferris, 1989). Typically, mean stability constants of metal-bacterial-surface interactions (Simoes Gonçalves et al., 1987) are higher than stability constants of metal-citrate complexes, but lower than those of metal-EDTA complexes (Martell \& Smith, 1974). This could explain why no reduced EDTA uptake rates were measured in the absence of metal ions even if - in analogy to citrate transport in B. subtilis - only the metal-complexed chelating agent was transported.

\section{Metal balance}

If metal-complexed EDTA is the form taken up, the question arises how bacteria cope with the large amounts of metal ions entering the cell to prevent excessive intracellular cation concentrations. One strategy could be to precipitate the metal ions as insoluble salts, e.g. calcium phosphates. Alternatively, cells could excrete the divalent cations, or they could employ both mechanisms simultaneously. EDTA-grown cells exhibited dark inclusion bodies containing high amounts of $\mathrm{Ca}^{2+}$ and $\mathrm{Mg}^{2+}$, an observation that supports the precipitation mechanism. However, considering the speciation of EDTA in the growth medium $[58.3 \%$ of the total EDTA is complexed with $\mathrm{Mg}^{2+}$ and $41 \cdot 1 \%$ with $\mathrm{Ca}^{2+}$ as calculated with ChemEQL (Müller, 1996)] and a growth yield of strain DSM 9103 on EDTA of $0 \cdot 26$, one can calculate that the cations would account for about $40 \%$ of the cell mass when they are taken up 
together with EDTA and remain as precipitates inside the cells. Also considering the counter-ions in these precipitates would more than double this figure. This high percentage argues against an exclusive usage of the precipitation mechanism. Indeed, ${ }^{45} \mathrm{Ca}^{2+}$ uptake in the presence of EDTA was markedly lower than that of $\left[{ }^{14} \mathrm{C}\right]$ EDTA. Moreover, radioactivity from ${ }^{45} \mathrm{Ca}^{2+}$ associated with the cells decreased drastically when EDTA uptake slowed or stopped. Therefore, excretion of $\mathrm{Ca}^{2+}$ seems to take place. $\mathrm{Ca}^{2+}$ extrusion mechanisms are probably present in all bacteria to maintain low intracellular $\mathrm{Ca}^{2+}$ concentrations (Lynn \& Rosen, 1987). We therefore assume a simultaneous utilization of both mechanisms by DSM 9103 cells to enable them to regulate the internal metal ion concentration.

\section{ACKNOWLEDGEMENTS}

This work was financially supported by BUWAL.

We are indebted to J. Leveau, A. Lück and H.-P. Gautschi for technical assistance. We also thank T. Greindl and L. Siggel (BASF) for the generous gift of ED3A and the EDDA isomers. We are also indebted to D. Hüglin (Ciba Chemikalien) for supplying us with $(\mathbf{S}, \mathbf{S})$-EDDS.

\section{REFERENCES}

Alder, A. C., Siegrist, H., Gujer, W. \& Giger, W. (1990). Behaviour of NTA and EDTA in biological wastewater treatment. Water Res 24, 733-742.

Bergsma, J. \& Konings, W. N. (1983). The properties of citrate transport in membrane vesicles of Bacillus subtilis. Eur J Biochem 134, 151-156.

Bradford, M. M. (1976). A rapid and sensitive method for the quantitation of microgram quantities of protein utilizing the principle of protein-dye binding. Anal Biochem 72, 248-254.

Cebulla, I. (1995). Gewinnung komplexbildender Substanzen mittels Amycolatopsis orientalis. $\mathrm{PhD}$ thesis, Eberhard-KarlsUniversität Tübingen.

Cornish-Bowden, A. (1974). A simple graphical method for determining the inhibition constants of mixed, uncompetitive and non-competitive inhibitors. Biochem J 137, 143-144.

Dixon, M. (1953). The determination of enzyme inhibitor constants. Biochem J 55, 170-171.

Egli, T., Weilenmann, H. U., El-Banna, T. \& Auling, G. (1988). Gram-negative, aerobic, nitrilotriacetate-utilizing bacteria from wastewater and soil. Syst Appl Microbiol 10, 297-305.

Ferris, F. G. (1989). Metallic ion interactions with the outer membrane of Gram-negative bacteria. In Metal lons and Bacteria, pp. 292-323. Edited by T. J. Beveridge \& R. J. Doyle. New York: Wiley.

Frank, R. \& Rau, H. (1989). Photochemical transformation in aqueous solution and possible environmental fate of ethylenediaminetetraacetic acid (EDTA). Ecotoxicol Environ Saf 19, $55-63$.

Gschwind, N. (1992). Biologischer Abbau von EDTA in einem Modellabwasser. Gwf Wasser Abwasser 133, 546-549.

Hantke, K. \& Braun, V. (1975). Membrane receptor dependent iron transport in Escherichia coli. FEBS Lett 49, 301-305.

Henneken, L., Nörtemann, B. \& Hempel, D. C. (1995). Influence of physiological conditions on EDTA degradation. Appl Microbiol Biotechnol 44, 190-197.

Houriet, J.-P. (1996). NTA dans les eaux. Cahier de l'environment 264. Berne: Office fédéral de l'environnement, des forêts et du paysage (OFEFP).

Kari, F. G. (1994). Umweltverhalten von Ethylendiamintetraacetat (EDT A) unter spezieller Berücksichtigung des photochemischen Abbaus. PhD thesis, Swiss Federal Institute of Technology.

Kari, F. G. \& Giger, W. (1995). Modeling the photochemical degradation of ethylenediaminetetraacetate in the river Glatt. Environ Sci Technol 1995, 2814-2827.

Kari, F. G. \& Giger, W. (1996). Speciation and fate of ethylenediaminetetraacetate (EDTA) in municipal wastewater treatment. Water Res 30, 122-134.

Kari, F. G., Hilger, S. \& Canonica, S. (1995). Determination of the reaction quantum yield for the photochemical degradation of Fe(III)-EDTA : implications for the environmental fate of EDTA in surface waters. Environ Sci Technol 29, 1008-1017.

Klopp, R. \& Patsch, B. (1994). Organische Komplexbildner in Abwasser, Oberflächenwasser und Trinkwasser, dargestellt am Beispiel der Ruhr. Wasser Boden, 32-37.

Kluner, T., Hempel, D. C. \& Nörtemann, B. (1998). Metabolism of EDTA and its metal chelates by whole cells and cell-free extracts of strain BNC1. Appl Microbiol Biotechnol 49, 194-201.

Konings, W. N., Hellingwerf, K. J. \& Robillard, G. T. (1981). Transport across bacterial membranes. In Membrane Transport, pp. 257-283. Edited by S. L. Bonting \& J. J. H. H. M. Pont. Amsterdam/New York/Oxford: Elsevier/North-Holland Biomedical Press.

Lahl, U. \& Burbaum, H. (1988). Einzelstoffanalysen im Zu- und Ablauf einer kommunalen Kläranlage. Korrespondenz Abwasser 35, 360-364.

Lauff, J. J., Steele, D. B., Coogan, L A. \& Breitfeller, J. M. (1990). Degradation of the ferric chelate of EDTA by a pure culture of an Agrobacterium sp. Appl Environ Microbiol 56, 3346-3353.

Lynn, A. R. \& Rosen, B. P. (1987). Calcium transport in prokaryotes. In Ion Transport in Prokaryotes, pp. 181-201. Edited by B. P. Rosen \& S. Silver. London: Academic Press.

Martell A. \& Smith, R. (1974). Critical Stability Constants, vol. 1, Amino Acids. New York: Plenum.

Maller, B. (1996). ChemEQL: a program to calculate chemical speciation equilibria titrations, dissolutions, precipitation, adsorption, simple kinetics, and pX-pY diagrams. Kastanienbaum, Switzerland: Swiss Federal Institute for Environmental Science and Technology (EAWAG).

Nörtemann, B. (1992). Total degradation of EDTA by mixed cultures and a bacterial isolate. Appl Environ Microbiol 58, 671-676.

Nowack, B. (1996). Behaviour of EDTA in Groundwater - a Study of the Surface Reactions of Metal-EDT A Complexes. PhD thesis, Swiss Federal Institute of Technology.

Palumbo, A. V., Lee, S. Y. \& Borman, P. (1994). The effect of media composition on EDTA degradation by Agrobacterium sp. Appl Biochem Biotechnol 45/46, 811-822.

Payne, J.W., Bolton, H. J., Campbell, J. A. \& Xun, L. (1998). Purification and characterization of EDTA monooxygenase from the EDTA-degrading bacterium BNC1. J Bacteriol 180, 3823-3827.

Reynolds, E. S. T. (1963). The use of lead citrate at high $\mathrm{pH}$ as an electron opaque stain in electron microscopy. J Cell Biol 17, 208-212. 
Simoes Gonçalves, L. M., Sigg, L., Reutlinger, M. \& Stumm, W. (1987). Metal ion binding by biological surfaces: voltametric assessment in the presence of bacteria. Sci Total Environ 60, $105-119$.

Uetz, T., Schneider, R., Snozzi, M. \& Egli, T. (1992). Purification and characterization of a two-component monooxygenase that hydroxylates nitrilotriacetate from 'Chelatobacter' strain ATCC 29600. J Bacteriol 174, 1179-1188.

Wilberg، E. (1989). Zur Physiologie und Ökologie Nitrilotricatetat (NTA) abbauender Bakterien. PhD thesis, Swiss Federal Institute of Technology.

Willecke, K., Gries, E.-M. \& Oehr, P. (1973). Coupled transport of citrate and magnesium in Bacillus subtilis. J Biol Chem 248, 807-814.

Witschel, M., Weilenmann, H.-U. \& Egli, T. (1995). Degradation of EDTA by a bacterial isolate. Poster presented at the 54th Annual
Meeting of the Swiss Society of Microbiology, Lugano, Switzerland. Abstract book, p. 146.

Witschel, M., Nagel, S. \& Egli, T. (1997). Identification and characterization of the two-enzyme system catalyzing the oxidation of EDTA in the EDTA-degrading bacterial strain DSM 9103. J Bacteriol 179, 6937-6943.

Wong, P. T. S., Liu, D. \& McGirr, D. J. (1973). Mechanisms of NTA degradation by a bacterial mutant. Water Res 7, 1367-1374.

Xu, Y., Mortimer, M. W., Fisher, T. S., Kahn, M. L., Brockman, F. J. \& Xun, L. (1997). Cloning, sequencing, and analysis of a gene cluster from Chelatobacter beintzii ATCC 29600 encoding nitrilotriacetate monooxygenase and NADH:flavin mononucleotide oxidoreductase. J Bacteriol 179, 1112-1116.

Received 9 October 1998; revised 14 December 1998; accepted 22 December 1998. 